\title{
Title: Causes of Rural-Urban Migration and Its Effect on Quality of Life
}

\author{
Received: 09-Nov-2020 | Accepted: 05-Jan-2021
}

\section{Riffat Rehman' ${ }^{1}$ Muqaddas Mazhar ${ }^{2}$ | Sadia Khan ${ }^{3}$ | Humaira Waseem ${ }^{4}$}

\begin{abstract}
The important theme of the current research is to investigate the causes of migration and its effect on quality of life. The main objective of the study was to see the effect of migration on household income in rural areas of Punjab-Pakistan especially in district vehari. A total of 322 sampled respondents were purposively interviewed. The study indicates that about $71 \%$ of the total respondents migrated with their families during the period (2008-2017). The study revealed that, quality of education, and employment and family conflict were observed as major causes of rural-urban migration. Due to non-parametric distribution of data Wilcoxon Signed Rank Test was used to see before and after effect of migration on household income and expenditures. To check the hypothesis regression analysis has been conducted. The Moreover, after migration the monthly income and expenditure of the respondents increased. The earning members of $66.8 \%$ of the respondents increased after migration. The joint families were scattered in to nuclear family. Before migration business were the main occupation of about $42 \%$ of the respondents while after migration most of them were engaged with private jobs and some have their own business. The education ratio of $85.3 \%$ of the respondents increased with migration. Positive changes have been observed in pre and post facilities under consideration. It is concluded from the result that education was the major cause that enhance the quality of life. It is recommended that basic facilities like education, health and creation of off-farm jobs, improved training opportunities and development programs should be provided to rural peoples. It also depicts several empirical studies conducted in different countries.
\end{abstract}

Keywords: Rural-Urban Migration, Push and Pull Factors, Education Quality of Life

Author's Affiliation:

Institution: The University of Lahore ${ }^{1,2,3,4}$

Country: Pakistan ${ }^{1,2,3,4}$

Corrsponding Author's Email: *

The material presented by the author(s) does not necessarily portray the view point of the editors and the management of the ILMA University, Pakistan.

2709-2232 (Online) (C2021, published by the ILMA University, Pakistan.

This is open access article under the license. https://creativecommons.org/licenses/by/4.0/ 


\section{INTRODUCTION}

Migration is one of the important factors which are considered as opportunity to develop the socio-economic status of people, who have low socio-economic level. This study in concern to investigate the quality of life that gets the opportunity of migration. According to the Mularska-Kucharek, (2015) quality of life is the primary objective of any human activity. WHOQOL (1995) developed the sense of quality of life concern with physical, social and psychological wellbeing. Domestic migration directly links with quality of life. Chen et al., (2017) discussed the importance of migration its impact on quality of life and also indicated that there is positive link between quality of life and migration. According to the Lewis model of economic development people is moving rural area to urban area for searching the employment opportunity, education, social facilities and health care (Farooq, 2006).According to the Kalanauri, (2009) to resolve their socio economics issues which raised in daily life, they are creating opportunity to solve themselves. Literature review identified that pull and push factors which cause of migration like, political, social and caste system in the area. Modernization in developed country which create the employment opportunities and attract poor people to move in urban area for employment. Due to unavailability and limited sources per capita of labor is decreasing. Furthermore, technological advancement in industrial sector is one of the important factors which case of migration. In the rural area, there is better economic condition, better facility of life, increase in wages, transportation and communication advancement in developed area also attack the people to migrate (Datta, 1998, 2002; Solimano, 2002). Violence against female in growth phenomena, according to Devries et al., (2013) one out of fifteen women was affecting. Government policies and some domestics reasons both are causes of the domestic migration. These domestic migration increases of rural to urban in Pakistan and one of the phenomena is implementation of development plan and different development schemes in Pakistan. According to the literature review some push and pull effect identified. Mainly pull and push effect are social, caste system and some political influence. One of the factor is employment opportunities because in rural areas have less employment opportunities which cause the low per capita share of labor in the available sources in rural area like limited agriculture land and old methods of cultivation. Industrial growth also is the one of the important factor which has less growth which cause low economic condition, low wage rate, sanitation system and low communication skill and transportation. Most important but ignored factor is health facilities (Datta, 1998, 2002; Solimano, 2002). According to the Borjas, (2001) identified that family and friends also play important role for domestic people to migrate from domestic place to urban area. Pakistan considered as developing country in this context 10 million people which is $8 \%$ of total population migrated to urban to rural area of Pakistan which creating the burden on urban area(Government of Pakistan, 1998). Furthermore, on the positive side it's also reducing the burden on agricultural land. So, migration also considered as opportunity for unemployed people work of agriculture sector. On the other hand, it's also create the negative impact because skilled and educated people preferred to live in big cities to improve their quality of life. Ahmed, Akram\&Hussain (2005) identified the pull and push factors of migration different policies and social factors. Secondly creating the employment opportunity, third, limited area of cultivation 
land and low per capita share of labor, forth, improve the economic condition by getting higher wages, basic facilities. Fifth, enclosure of industrial experience is Unemployment, poverty, inadequate facilities of quality of education and health facility. These are the problem facing by people and to resolve their economic, social, educational and political problem people of manually migrate to other developed cities of Pakistan.

Violence against female in growth phenomena, according to Devries et al., (2013) one out of fifteen women was affecting. Government policies and some domestic reasons both are causes of the domestic migration. These domestic migration increases of rural to urban in Pakistan and one of the phenomena is implementation of development plans and different development schemes in Pakistan.

The present examination means to examine the sex measurements of rustic to urban migration, and investigates the wonder of family migration in country to urban migration. The investigation leaves from customary way to deal with sex based approach. The conventional methodology depends on amassed information, which expects that the causes and outcomes of ladies and men migration are the equivalent. In reality the case isn't so; the experience of migration needs to examine independently for people since they hold diverse financial job in family and in the public arena. This examination will improve our insight in sexual orientation measurements of inner migration. The examination especially plans to investigate the two questions:

1. Has the sample of internal migration changed after some time?

2. Have the causes of migration affect the quality of life?

\section{Push and Pull Factors}

A Push Factor is the reason or condition that drives out individuals from their current location

While a Pull Factor is the one that attracts them to move in a particular area. The table below

Summarizes some of the push and pull factor under each head.

\begin{tabular}{|c|c|c|}
\hline \multicolumn{3}{|c|}{ Factors Influencing Migration } \\
\hline Reason & د & Pull Factors \\
\hline Socio-Economic & $\begin{array}{l}\rightarrow \text { Relatively low income } \\
\rightarrow \text { Unemployment } \\
\rightarrow \text { Land shortage } \\
\rightarrow \text { Negative Amenities } \\
\rightarrow \text { Demographics } \\
\rightarrow \text { State polices }\end{array}$ & $\begin{array}{l}\rightarrow \text { Industrial growth } \\
\rightarrow \text { Employment } \\
\rightarrow \text { Investment } \\
\rightarrow \text { Positive Amenities } \\
\rightarrow \text { Demographics } \\
\rightarrow \text { Social Network }\end{array}$ \\
\hline Cultural & $\begin{array}{l}\rightarrow \text { Political instability } \\
\rightarrow \text { Ethnic clashes }\end{array}$ & $\begin{array}{l}\rightarrow \text { State policies } \\
\rightarrow \text { Mega socio-cultural } \\
\text { opportunities }\end{array}$ \\
\hline Environmental & $\begin{array}{l}\rightarrow \text { High risk of natural } \\
\text { disasters } \\
\rightarrow \text { Extreme climates } \\
\rightarrow \text { Pollution }\end{array}$ & $\begin{array}{c}\rightarrow \text { Low risk of natural } \\
\text { disasters }\end{array}$ \\
\hline
\end{tabular}




\section{LITERATURE REVIEW}

Travelling to an innovative residence is a worrying and exciting procedure. The firstly and great item immigrants take to organize to find a job to earn money. If a migrant fails to find a job or loses his/her job, he or she could be struggling to survive, leading to a poor QOL. Previous studies have reported that unemployment is significantly associated with poor mental health in both migrants and the general population (Chen et al. 2012; Paul and Moser 2009), suggesting the significance of secure employment in promoting QOL for people of working-age. In addition, for most migrants, having a job and creating work-related interpersonal interactions is the primary social process by which they adapt and integrate themselves into the society in their new destination (Aycan and Berry 1996). The type of job a migrant is able to find may affect his/her subjective well-being. Among various employment-related factors, job security is of particular significance. Lack of job security is a sense of no assurance of employment continuity and a lack of selfcontrol of the employment conditions (Probst 2003). The QOL of an individual might not be high if he does not feel that he is in control of his employment status and is always worried about losing his job. For example, a prospective cohort study among 3360 white-collar office workers revealed that moving from more secure jobs to less secure jobs was associated with poor self-rated health, greater risk of hypertension, and increased odds of depression (Ferrie et al. 2002). The QOL might not be high if workers are not satisfied with their current job (Faragher et al. 2005; Cimete et al. 2003). When individuals feel satisfied in their work, they will be much more likely to enjoy their job, keep a good mood, and have fewer health problems, leading to an overall better well-being (Cimete et al. 2003). Many factors negatively affect job satisfaction, including a high demand job with low pay, a lack of opportunities for promotion, and poor relationships with co-workers (Erlinghagen 2008; Vandenberg he et al. 2011; Ferrie et al. 2002; Faragher et al. 2005; Cimete et al. 2003). Among these factors, having a secure job is of great significance (De Witte and Na"swall 2003; Buitendach and De Witte 2005; Guest and Conway 1997; Cimete et al. 2003). People tend to secure a job they like, and working on a job a person likes is associated with high job satisfaction (Probst 2002). On the other hand, the threat caused by the possibility of unemployment prevents workers from feeling satisfied in the workplace. For instance, compared with workers with secure jobs, workers with insecure jobs are less likely to feel satisfied with current salary and opportunities for promotion (Probst 2002). Furthermore, people with a secure job have stronger feelings that they are under control of their employment and are less likely to worry about losing their job, enhancing job satisfaction (De Witte and $\mathrm{Na}$ "swall 2003). Lastly, people with insecure or unsatisfying jobs are more likely to have a heightened intention for job change and to spend more time and efforts on job searching (Chen et al. 2011; Egan et al. 2004; Sverke et al. 2002; Probst 2002). Intending to change jobs and job searching are both highly stressful, distracting a person from focusing on their current job, and reducing their time and effort focused on enjoying life. As a result, people who are consistently looking for jobs are more likely to have poor QOL (Vandenberghe et al. 2011).

The value of work for the folks, their lives and their intelligence of comfort has been glowing recognized (see, e.g., Blustein2008; Warr1987, 2007). The centrality 
of work to the immigrants' well-being is understandable. Separately from given that earnings, work offers opportunities for public communication and meeting with the swarm the public. Furthermore, work enhances the immigrants' dynamic roles in the swarm civilization, their character and self-respect (Beiser and Hou2001), and studies explain that require of service is connected with the emotional pain feel by a lot of immigrants (Aycan and Berry 1996; Khawaja and Mason 2008). The economic aspect of the sensation of migration wants to remain mostly highlighted. In corresponding by common revolution, the reduction in prerequisite for labor force clues some people of rural zones to towns so for example to discovery innovative parts of service The feature succeeding people actions in current biosphere conquered through entrepreneur economy is transfer of labor force(Kaya, 2015). Therefore, seeing journey simply by way of a substance of residents movement can cause ignorance of the various economic roles the migrants. Migration affects both society receiving migration and the one causing emigration is a collective activity caused by social change. The portent of migration is one of the supreme important signs of common variation, particularly in current periods the variations happened in outdated common arrangement and associations of manufacture shaped the miracle of relocation after rural areas to the urban. Manufacturing Insurrection and the supplementary procedure of development have particularly be situated conclusive in rapports of path and subtleties of the marvel of immigration(Kaya, 2015). Some reasons leading surplus rural population to a city are pull factors. The pull factors of urbanization can be listed as follows: income differences between villages and cities, a better and further education, charm of the city, expectation for discovery a job, advance devalues of breathing and conveyance services.

\section{Theoretical Frame Work}

Causes of migration impact on quality of life. There are four dimensions under causes of migration which is family conflict, job opportunities, children study and political issues. These are independent variables. Physical wellbeing and emotional wellbeing are the mediating variable and quality of life is dependent variables.

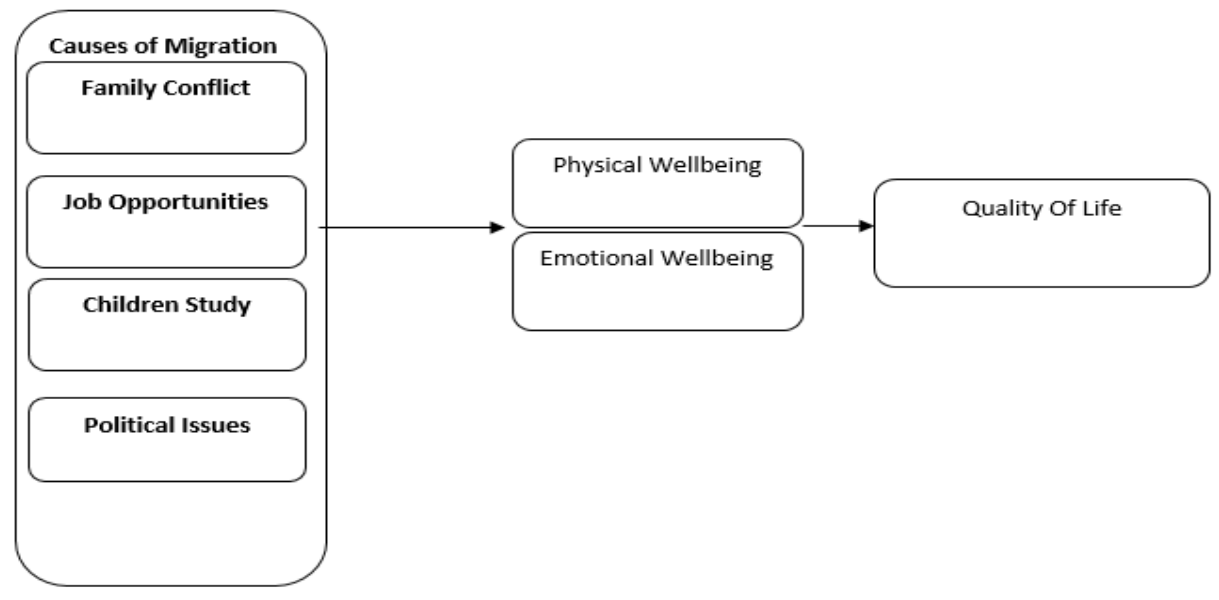




\section{RESEARCH METHODOLOGY}

Sample Technique

In all the shape of investigation it might be well to evaluate the whole population. Conversely within the maximum circumstances the population is too large. Therefore it is impossible to analyses each individual in research.

Non probability sampling techniques is used in this research .Non Probability Sampling which is further divided in five type of sampling that convenient sampling. A best thing about convenient sampling is the ease of assembling the sample. Convenience sampling, which involves choosing a sample based on the people who are readily available.

Investigations have been adopted. In many creating countries interviews by telephone or mail are not adopted in light of the fact that the result is often dicey (Overton and Diermen 2003). Despite the fact that from one perspective the individual questionnaire as a rule acquires a higher reaction, in excess of a telephone or postal questionnaire, it additionally takes additional time (Hoggart, Lees, and Davies 2002).Total of 322 migrate people were interviewed in the city Vehari using non probability convenient sampling. It is a straightforward and simple method of choosing a probability sample that contains certain statistical idiosyncrasy as the initial chance of selection of any component is equivalent (Robson 2002), which way all migrants have an equivalent possibility of appear in the example. In shape to attain a quite high-quality illustration of the residents in survey; randomly household was selected in the chosen area. Uncommonly the chosen people were not available at the moment of the survey; therefore the investigators have to leave to the next people. The questionnaires were undertake by the investigator and three investigate assistant who were born and bred in district Vehari and were therefore familiar with the situation in the vehari city, had good knowledge of functioning in ground study, and have spoken their willingness to take out the survey and toward perform the interviews .universal interviewing ability in family member to contact participant and recruit collaboration, how to contract by means of knowledgeable and untrained head of families in conditions of hand the questionnaire and tape the response, moreover privacy issue. In additional expressions, to make sure that everyone members of the panel be mastered the ground effort. After that they separated into three groups and work unconnectedly. Therefore, group was very well prepared, which enable the instigator to whole the ground effort prior than be hopeful. The questionnaires were conduct in three portions, defined as migrantreceiving facilities, each of which restricted elevated quantity of migrants in unstable circumstances in conditions of socio-economic stratum, accommodation and backdrop. In chosen these three parts based on residents censuses, the accessible studies were examined, and the financial and community factor measured. beginning the start, it was tell them in detail to the questionnaire respondents that the purpose of the research was for a Master of Science (MS) thesis, to guarantee them so as researchers were not government workers and so as to this was not an executive study for limited establishment (Council Tax, Department of Statistics, Committee of Financial Inspection and Social Security). This allowable they suffer open to state their views and thoughts and on the way to respond the questions honestly. 
The participants were too provided through an in order slip which explained the reason of the research, reasons why they have been chosen, that their contribution would stay secret, and so as to their contribution in the research have been voluble so that they was openly to take out at any time and without telling any reason and clarification. Moreover, they were not necessary to give their name. Moreover, knowledgeable permission was obtained (the original was retained through the investigatory a duplicate specified to the contributor). Lastly, they were asked to respond each the questions openly. It is possibly, important to spot away that the investigator had been familiarity of moving away questionnaires through his knowledge for a Master's degree, and so he knew how to set up excellent connection with the respondents. In a few casing, people in district Vehari have become known with such surveys on diverse aspects of source of revenue values.

The questionnaire was planned to gathering turn concerning the following areas: I. The first section was designed to obtain general information from the head of the household: age, sex, place, marital status, educational status and number of family members, etc.

II. The second section focused on general issues about the period before migration: age at the time of arrival, educational status, marital status, income, employment, type of accommodation, ownership of house, reasons for leaving their last place of residence and the reasons for moving to district vehari, etc.

III. Third section was designed to examine the migrant's housing condition after migration: available facilities after migration in terms of visits there, owner ship of housing, ways of earn money, etc.

IV. The fourth section concerned information about housing and living conditions in district vehari: ownership and type of housing, numbers of people living in the house, access to electricity, and level of education increased in family or quality of life are improved or not, physical wellbeing or emotional wellbeing.

\section{RESULTS}

\section{Demographic Characteristics of the Survey}

\begin{tabular}{|l|c|c|}
\hline Respondent Demographics & Frequency & Percentage \\
\hline Age group (N=322) & & \\
\hline 10-20 years & 20 & 6.2 \\
\hline 21-30 years & 197 & 61.2 \\
\hline 31-40 years & 89 & 27.6 \\
\hline 41-50 years & 16 & 5.0 \\
\hline Location $(\mathbf{N}=\mathbf{3 2 2})$ & & \\
\hline
\end{tabular}




\begin{tabular}{|c|c|c|}
\hline Urban & 299 & 92.9 \\
\hline Rural & 23 & 7.1 \\
\hline \multicolumn{3}{|l|}{ Marital Status $(\mathrm{N}=322)$} \\
\hline Married & 165 & 51.2 \\
\hline Unmarried & 157 & 48.8 \\
\hline \multicolumn{3}{|c|}{ Educational Status $(\mathrm{N}=322)$} \\
\hline Literate & 307 & 95.3 \\
\hline Illiterate & 15 & 4.7 \\
\hline \multicolumn{3}{|c|}{ Level of Education $(\mathrm{N}=322)$} \\
\hline Primary & 9 & 2.8 \\
\hline Middle & 6 & 1.9 \\
\hline Matric & 9 & 2.8 \\
\hline F.A/FSc & 25 & 7.8 \\
\hline B.A/BSc & 201 & 62.4 \\
\hline M.A/MSc & 43 & 13.4 \\
\hline Any Other & 29 & 9.0 \\
\hline \multicolumn{3}{|c|}{ Number of Family Members $(\mathrm{N}=322)$} \\
\hline 1-3 Members & 28 & 8.7 \\
\hline 4-6 Members & 158 & 49.1 \\
\hline 7-9 Members & 111 & 34.5 \\
\hline 10-12 Members & 25 & 7.8 \\
\hline \multicolumn{3}{|c|}{ Period of Migration $(\mathrm{N}=322)$} \\
\hline Less Than 10 Years & 193 & 59.9 \\
\hline
\end{tabular}




\begin{tabular}{|l|c|c|}
\hline More Than 10 Years & 129 & 40.1 \\
\hline Area of Migration (N=322) & & \\
\hline Rural & 124 & 38.5 \\
\hline Sub Urban & 78 & 24.2 \\
\hline Urban & 120 & 37.3 \\
\hline
\end{tabular}

Table illustrates that $6.2 \%$ of the sampled respondents belonged to the age group $10-20$ years, $61.2 \%$ and $27 \%$ of sampled respondents were in the age group 21-30 and 31-40 years respectively. 5.0 of the sampled respondents had age 41-50. The Mean age of the participants was $19.1+6.3$ years. The minimum age was 17 years and maximum age was 50 years as shown in above table. Shows the frequency of location migrated respondents $92.9 \%$ respondent were in urban areas and 7.1 respondents belong to rural areas. . A total of 322 participants table 1 concludes that about $(51.2 \%)$ of the sample respondents were married while the rest $(48.8 \%)$ were unmarried. about educational status out 322 sample $95.3 \%$ people in district vehari are literate or $4.7 \%$ participants are illiterate. Out of total $(95 \%)$ literate $(2.8 \%)$ of the sampled respondents were having education up to primary level, $(1.9 \%)$ were up to middle, $(2.8 \%)$ were up to matric, $(7.8 \%)$ were up to intermediate, $(62.4 \%)$ were graduates, $(13.4 \%)$ were master degree holders while the remaining $(9.0 \%)$ were doctors. .7\% respondents (1-3) family members $49.1 \%$ respondents are (4-6) family members in home $34.5 \%$ was (7-9) family members and $7.8 \%$ people fall in (10-12) family members. Data showed that majority (4-6) members have at home.

Table shows that $59.9 \%$ of the sampled respondents were migrated in the period of less than ten years about $40.1 \%$ of sampled respondents were migrated in the period of more than ten years. Table illustrates that majority $75.3 \%$ of sampled respondents came from rural areas.

Causes of Migration:

\begin{tabular}{|l|c|c|}
\hline Causes of Migration & Frequency & Percentage \\
\hline Migrate with (N=322) & & \\
\hline Family & 135 & 41.9 \\
\hline Alone & 187 & 58.1 \\
\hline Migration Due To Enmity (N=322) & & \\
\hline Yes & 67 & 20.1 \\
\hline
\end{tabular}




\begin{tabular}{|c|c|c|}
\hline No & 255 & 79.2 \\
\hline \multicolumn{3}{|c|}{$\begin{array}{l}\text { Migration Due To War Against Terrorism } \\
(\mathrm{N}=322)\end{array}$} \\
\hline Yes & 19 & 5.9 \\
\hline No & 303 & 94.1 \\
\hline \multicolumn{3}{|c|}{$\begin{array}{l}\text { Migration Due To Religious Harassment } \\
(\mathbf{N}=322)\end{array}$} \\
\hline Yes & 10 & 3.1 \\
\hline No & 312 & 69.9 \\
\hline \multicolumn{3}{|c|}{ Migrate Due To Family Conflict $(\mathrm{N}=322)$} \\
\hline Yes & 59 & 18.3 \\
\hline No & 263 & 81.7 \\
\hline \multicolumn{3}{|c|}{ Migrate Due To Health Facilities } \\
\hline Yes & 114 & 35.4 \\
\hline No & 280 & 64.6 \\
\hline \multicolumn{3}{|c|}{$\begin{array}{l}\text { Migrate Due to Better Education Facilities at } \\
\text { city }\end{array}$} \\
\hline Yes & 257 & 79.8 \\
\hline No & 65 & 20.2 \\
\hline \multicolumn{3}{|c|}{$\begin{array}{l}\text { Migrate because of Employment } \\
\text { Opportunities At City }\end{array}$} \\
\hline Yes & 238 & 73.9 \\
\hline No & 84 & 26.1 \\
\hline
\end{tabular}

Data regarding migration with family or alone is given in table. The data shows that majority $(58.1 \%)$ of sampled respondents were migrated alone while $(41.9 \%)$ of the sampled respondents were migrated with their family. Table as a whole conclude that majority of the sampled respondents were migrated alone because most of the respondents leave their native land due to push factors that's why they migrated 
alone and along with their families. 20.1\% respondent says that they were migrate due to enmity and $79.2 \%$ respondents says that they were not migrate due to enmity they migrate some others factors.

A total respondents $322(5.9 \%)$ migrated due to war against terrorism and $94.1 \%$ migrate other pull and push factors. As a whole table shows that a minimum ratio of people migrates due to war. Shows that total 322 respondents $3.1 \%$ people left their native land due to religious harassment. Table illustrates that majority $18.3 \%$ respondents migrate due to family conflict. In the research area push factors are enmity at village, familial conflict, religious harassment, inadequate health facilities and war against terrorism

Table showing that total 322 respondents and $35.4 \%$ respondents migrate due to health facilities. They leave their native land due to insufficient health facilities. Table showed that total sample size of migrated people was 322. Out of 322 respondents $79.8 \%$ migrate due education facilities. They leave their native land due to children education. Many family migrate for child study because in rural area higher and better education system not available. Table illustrate Distribution of respondents on the basis of pull factors migrate due to employment opportunities in urban areas $73.9 \%$ respondents migrate for new job experience and better employment opportunities.

\begin{tabular}{|c|c|c|c|c|}
\hline \multicolumn{5}{|c|}{ Model Summary } \\
\hline Model & R & R Square & $\begin{array}{c}\text { Adjusted R } \\
\text { Square }\end{array}$ & $\begin{array}{l}\text { Std. Error of } \\
\text { the Estimate }\end{array}$ \\
\hline 1 & $.479 \mathrm{a}$ & .230 & .217 & .88466314 \\
\hline
\end{tabular}

Table no. 1

Assumption of Regression (BAR) is satisfied through R square i.e 0.230.

\begin{tabular}{|c|c|c|c|c|c|c|}
\hline \multicolumn{7}{|c|}{ Coefficients } \\
\hline \multirow{2}{*}{\multicolumn{2}{|c|}{ Model }} & \multicolumn{2}{|c|}{$\begin{array}{l}\text { Unstandardized } \\
\text { Coefficients }\end{array}$} & $\begin{array}{l}\text { Standardized } \\
\text { Coefficients }\end{array}$ & \multirow[t]{2}{*}{$\mathrm{t}$} & \multirow[t]{2}{*}{ Sig. } \\
\hline & & B & Std. Error & Beta & & \\
\hline \multirow[t]{2}{*}{1} & (Constant) & -1.174 & .339 & & -3.461 & .001 \\
\hline & $\begin{array}{l}\text { You migrate } \\
\text { due to enmity } \\
\text { at village }\end{array}$ & .875 & .129 & .356 & 6.778 & .000 \\
\hline
\end{tabular}




\begin{tabular}{|l|l|l|l|l|l|}
\hline $\begin{array}{l}\text { You migrate } \\
\text { due to familial } \\
\text { conflict }\end{array}$ & .248 & .144 & .096 & 1.724 & .086 \\
\hline $\begin{array}{l}\text { You migrate } \\
\text { due to } \\
\text { inadequate } \\
\text { health facilities }\end{array}$ & -.110 & .122 & -.053 & -.899 & .369 \\
\hline $\begin{array}{l}\text { You migrate } \\
\text { due to better } \\
\text { educational } \\
\text { facilities at city }\end{array}$ & .160 & .135 & .064 & 1.186 & .237 \\
\hline $\begin{array}{l}\text { You migrate } \\
\text { because of } \\
\text { employment } \\
\text { opportunities at } \\
\text { city }\end{array}$ & -.679 & .128 & -.298 & -5.319 & .000 \\
\hline
\end{tabular}

Table no. 2

Migration due to health facilities and employment opportunities are inversely proportional to Quality of Life. Results from Migration due to enmity and employment opportunity at city are statistically significant. Moreover both of these variables are relatively more important in explaining QOL.

\begin{tabular}{|c|c|c|c|c|c|c|}
\hline \multicolumn{6}{|c|}{ ANOVAa } & \multirow[b]{2}{*}{ Sig. } \\
\hline & Model & $\begin{array}{c}\text { Sum of } \\
\text { Squares }\end{array}$ & df & $\begin{array}{l}\text { Mean } \\
\text { Square }\end{array}$ & $\mathbf{F}$ & \\
\hline \multirow[t]{3}{*}{1} & Regression & 73.689 & 5 & 14.738 & 18.831 & $.000 \mathrm{~b}$ \\
\hline & Residual & 247.311 & 316 & .783 & & \\
\hline & Total & 321.000 & 321 & & & \\
\hline
\end{tabular}

Table 3

Here $\mathrm{R}$ square is 0.230 , which means causes of migration are $23 \%$ measuring Quality of Life.

The results showed that model is significant as p-value is 0 . 


\section{DISCUSSION:}

The impact of migration in the present community is patent not solitary in the better-quality the existing ethics and lifecycle charms of the migrated families but moreover contact near acceptance of additional substantial position on schooling and well-being. Understanding the reputation of the part of simple schooling the expenditure on this discipline had improved significantly with the outcome that people acceptable both the girls and boys to develop assistance of education. With regular intake of healthy diet and positive style on availing the healthcare facilities the whole viewpoint of the families had improved. This chapter presents a picture of the main conclusion and judgments made in stroke with the theoretical backgrounds stated in the first two sections of the thesis (introduction and review of literature). The current discussion begins with the results of the study by maintaining a focus on the main objectives of the study and clarifying the success of this study in achieving these objectives. There is a positive impact have been observed in pre and post facilities of the migrated families.

\section{CONCLUSION:}

the effect of migration on household income in rural areas of Punjab-Pakistan especially in district Vehari, positive changes have been observed in pre and post facilities under consideration and it is recommended that basic facilities like education, health and creation of off-farm jobs, improved training opportunities and development programs should be provided to rural peoples this study open that migration have better the family unit revenue, quality of life and promoted the socioeconomic situation of the migrants at objective and it is the encouraging impact of the migration. Rural out-migration was surely linked with purpose of shortage decrease in the urban communities.

\section{REFERENCES:}

Mularska-Kucharek, M. (2015). Entrepreneurial activities of village residents. Journal of Agribusiness and Rural Development , (4 [38]).[1]

Cao, L., Zhang, C., Chen, H., Tsang, D. C., Luo, G., Zhang, S., \& Chen, J. (2017). Hydrothermal liquefaction of agricultural and forestry wastes: state-of-the-art review and future prospects. Bioresource technology, 245, 1184-1193.[2]

Glazer, S., Diesto, J., Crooks, P., Yeoh, H., Pascual, N., Selevan, D., \& Farooq, M. (2006). Going beyond the kidney disease outcomes quality initiative: hemodialysis access experience at Kaiser Permanente Southern California. Annals of vascular surgery, 20(1), 75-82.[3]

Kalanauri, Z. I. (2009). The Implementation Strategy for Successful Functioning of Musalihat Anjuman. Lahore: UNDP.[4]

Ahad, M. (2015). The Determinants of International Migration in Pakistan: New Evidence from Combined Cointegration, Causality and Innovative Accounting Approach.[5]

Dalen, J. E., \& Devries, S. (2014). Diets to prevent coronary heart disease 19572013: what have we learned?. The American journal of medicine, 127(5), 364369.[6]

Borjas, G. J. (2001). Does immigration grease the wheels of the labor market? 
Brookings papers on economic activity, 2001(1), 69-133.[7]

Saad, A., Waraich, I. A., \& Ijaz, M. (2014). Socio-Economic Effects of Microfinance on Agricultural Sector: An Analysis of Farmer's Standard of Life in Multan. International Review of Management and Business Research, 3(3), 1671.[8]

Dalen, J. E., \& Devries, S. (2014). Diets to prevent coronary heart disease 19572013: what have we learned?. The American journal of medicine, 127(5), 364369.[9]

Hinks, A., Cobb, J., Marion, M. C., Prahalad, S., Sudman, M., Bowes, J., \& Brown, M. (2013). Dense genotyping of immune-related disease regions identifies 14 new susceptibility loci for juvenile idiopathic arthritis. Nature genetics, 45(6), 664. $\{10\}$

Aycan, Z., \& Berry, J. W. (1996). Impact of employment-related experiences on immigrants' psychological well-being and adaptation to Canada. Canadian Journal of Behavioural Science/Revue canadienne des sciences du comportement, 28(3), 240.[11]

Hernandez, L., Probst, A., Probst, J. L., \& Ulrich, E. (2003). Heavy metal distribution in some French forest soils: evidence for atmospheric contamination. Science of the Total Environment, 312(1-3), 195-219.[12]

László, K. D., Pikhart, H., Kopp, M. S., Bobak, M., Pajak, A., Malyutina, S., ... \& Marmot, M. (2010). Job insecurity and health: a study of 16 European countries. Social science \& medicine, 70(6), 867-874.[13]

Qureshi, M. I., Rasli, A. M., \& Zaman, K. (2014). A new trilogy to understand the relationship among organizational climate, workplace bullying and employee health. Arab Economic and Business Journal, 9(2), 133-146.[14]

Hughes, T. P., Baird, A. H., Bellwood, D. R., Card, M., Connolly, S. R., Folke, C., ... \& Lough, J. M. (2003). Climate change, human impacts, and the resilience of coral reefs. science, 301(5635), 929-933.[15]

Chen, X., Yu, B., Gong, J., Wang, P., \& Elliott, A. L. (2018). Social capital associated with quality of life mediated by employment experiences: Evidence from a random sample of rural-to-urban migrants in china. Social indicators research, 139(1), 327-346.[16]

17- Du Plooy, C. (2008). Employees' work outcomes associated with the psychological contract within a service company (Doctoral dissertation, NorthWest University).[17]

Szymanski, E. M., \& Parker, R. M. (1996). Work and disability. Austin, Texas: Proed.[18]

Hinton, D. E., Nickerson, A., \& Bryant, R. A. (2011). Worry, worry attacks, and PTSD among Cambodian refugees: A path analysis investigation. Social science \& medicine, 72(11), 1817-1825.[19]

Neto, F., Wilks, D. C., \& Fonseca, A. C. M. (2019). Job-Related Well-Being of Immigrants. Social Indicators Research, 141(1), 463-475.[20]

Chong, J. X., Buckingham, K. J., Jhangiani, S. N., Boehm, C., Sobreira, N., Smith, J. D., ... \& Akdemir, Z. H. C. (2015). The genetic basis of Mendelian phenotypes: discoveries, challenges, and opportunities. The American Journal of Human Genetics, 97(2), 199-215.[21]

Overton, J., \& van Diermen, P. (2003). Using quantitative techniques in Scheyvens, R. \& Storey, D.(Eds)(2003) Development Fieldwork: A practical guide.[22]

McGuirk, P. M., \& O'Neill, P. (2016). Using questionnaires in qualitative human 


\section{geography.[23]}

Neto, F., Wilks, D. C., \& Fonseca, A. C. M. (2019). Job-Related Well-Being of Immigrants. Social Indicators Research, 141(1), 463-475.[24] 